\title{
PENERAPAN BIMBINGAN KELOMPOK DENGAN TEKNIK BRAINSTORMING UNTUK MENINGKATKAN KETERBUKAAN DIRI DALAM KOMUNIKASI PADA SISWA MAN KOTA PALANGKA RAYA
}

\author{
Sri Mariana', Helmuth Y. Bunu², Nopi Feronika ${ }^{3}$
}

\author{
'Universitas Palangkaraya, FKIP, Prodi BK \\ ${ }^{2}$ Universitas Palangkaraya, FKIP, Prodi BK \\ ${ }^{3}$ Universitas Palangkaraya, FKIP, Prodi BK \\ E-mail:Srimariana53@gmail.com
}

\begin{abstract}
ABSTRAK
Keterbukaan diri adalah proses memberi kesempatan kepada pihak lain untuk mengetahui cara kita berpikir, mengenai perasaan kita tentang sesuatu dan tentang keinginan. Siswa yang mampu dalam keterbukaan diri terbukti mampu menyesuaikan diri, lebih percaya diri, bersikap positif, lebih objektif, dan terbuka Tujuan penelitian ini untuk mengetahui sejauh mana teknik brainstorming untuk membantu siswa dalam meningkatkan keterbukaan diri dalam komunikasi pada siswa MAN Kota Palangka Raya. Jenis penelitian yang digunakan adalah Pre-Eksperimental Designs dengan One-group Pretest-Postets Design. Teknik pengambilan sampel dalam penelitian ini dilakukan dengan sampling purposive. Sampel dalam penelitian ini adalah 6 orang siswa MAN Kota Palangka Raya yang memiliki keterbukaan diri dalam komunikasi rendah. Alat pengumpulan data menggunakan angket keterbukaan diri dalam komunikasi. Sedangkan teknik analisis data yang digunakan adalah statistic non parametric dengan rumus uji-t dua sampel berpasangan. Dari hasil penelitian menujukkan keterbukaan diri dalam komunikasi sebelum memperoleh bimbingan kelompok dengan teknik brainstorming 50\% dengan kategori rendah, setelah memperoleh bimbingan kelompok dengan teknik brainstorming 69\% dengan kategori tinggi. Perbedaan tingkat keterbukaan diri dalam komunikasi sebelum dan sesudah diberikan bimbingan kelompok dengan teknik brainstorming sebesar $18 \%$. Hasil uji $t$ dua sampel berpasangan diperoleh $t$ hitung-12,548 dan $t$ tabel -2,0 I5 berarti Ha diterima. Hasil tersebut menunjukkan bahwa teknik brainstorming begitu efektif untuk meningkatkan keterbukaan diri dalam komunikasi pada siswa MAN Kota Palangka Raya.
\end{abstract}

Kata Kunci: Keterbukaan Diri; Brainstorming; Bimbingan Kelompok

\section{The Application of Group Guidance with Brainstorming Techniques to Increase Self-s Disclosure Communication in Students of MAN Palangka Raya City}

$$
\text { ABSTRACT (10 pt) }
$$

Self-disclosure is the process of giving the other party the opportunity to know how we think, how we feel about something, and about our desires. Students who are capable of self-openness are proven to be able to adjust, be more confident, have a positive attitude, be more objective, and open. The purpose of this study is to determine the extent to which brainstorming techniques are used to assist students in increasing self-disclosure in communication among students of MAN Palangka Raya City. The type of research used is Pre-Experimental Designs with One-group PretestPostets Design. The sampling technique in this study was carried out by purposive sampling. The sample in this study was 6 students of MAN Kota Palangka Raya who have low self-disclosure in communication. The data collection tool uses a self-disclosure questionnaire in communication. Meanwhile, the data analysis technique used is non-parametric statistics with paired two-sample t-test formula. The results of the study show self-openness in communication before receiving group guidance with the brainstorming technique of $50 \%$ in the low category, after receiving group guidance with the brainstorming technique of $69 \%$ with the high category. The difference in the level of self-disclosure in communication before and after being given group guidance with brainstorming techniques was $18 \%$. The results of the paired two-sample t-test obtained $t$ count- 12.548 and $t$ table -2.015 means that $\mathrm{Ha}$ is accepted. These results indicate that the brainstorming technique is so effective in increasing self-disclosure in communication among students of MAN Kota Palangka Raya.

Keywords: Self-Disclosure; Brainstorming; Group Guidance 
Vol. I, No. I, Tahun 202I e-ISSN .xxxxxxxxx

\section{PENDAHULUAN}

Komunikasi adalah suatu proses penyampaian pesan (ide atau gagasan) dari satu pihak ke pihak lain agar terjadi saling mempengaruhi antara keduanya. Dalam hal ini berkomunikasi siswa satu dengan yang lain saling mempengaruhi hingga terjadinya interaksiinteraksi dari kedua siswa tersebut. Dalam melakukan interaksi sosial harus didahului oleh kontak dan komunikasi, maka begitu pentingnya komunikasi dalam kehidupan. Komunikasi adalah peristiwa sosial, peristiwa yang terjadi ketika manusia berinteraksi dengan manusia yang lain. Melalui komunikasi kita menemukan diri kita, mengembangkan konsep diri, dan menetapkan hubungan kita dengan dunia di sekitar kita. Maka pengetahuan tentang diri itu penting untuk meningkatkan komunikasi, dimana dalam hal membuka diri kita bisa memahami individu satu dengan yang lainnya. Johnson (dalam Suriana \& Dewi, 2013) menunjukkan bahwa individu yang mampu dalam keterbukaan diri (self disclosure) akan dapat mengungkapkan diri secara tepat, terbukti mampu menyesuaikan diri (adaptive), lebih percaya diri sendiri, lebih kompeten, dapat diandalkan, lebih mampu bersikap positif, percaya terhadap orang lain, lebih objektif, dan terbuka.

Menurut Brooks dan Emmert 1997 (dalam Ashfahani, 2019), menyebutkan karakteristik sikap terbuka dalam komunikasi: (I) menilai pesan secara objektif dengan menggunakan data dan keajekan logika. (2) membedakan dengan mudah, melihat nuansa, dsb. (3) berorientasi pada isi. (4) mencari informasi dari berbagai sumber (5) lebih bersifat profesional dan mengubah kepercayaan. (6) mencari pengertian pesan yang tidak sesuai rangkaian kepercayaannya. Sedangkan dari pengamatan yang peneliti lihat, ada beberapa siswa yang bersikap tidak terbuka dalam hal komunikasi jika di lihat dari teori karakteristik sikap terbuka.

Dari hasil peneliti di MAN Kota Palangkaraya, diketahui ada beberapa siswa yang kurang memiliki sikap kurang terbuka dalam hal berkomunikasi dengan orang lain, seperti I) siswa kurang bersikap berorientasi pada isi. Contohnya siswa yang memilih saat pembagian kelompok karena alasan latar belakang temannya yang berbeda. 2) siswa kurang memiliki sikap mencari informasi dari berbagai sumber. Contohnya saat dapat informasi dari temannya, siswa langsung menerima saja tanpa mencari tau dari yang lain. 3) siswa kurang memiliki sikap mencari pesan tidak sesuai rangkaian kepercayaannya. Contohnya ada siswa saat diskusi/belajar bersama tidak mau terbuka menerima pendapat temannya yang berbeda dengan pendapat dia. Jika hal ini didiamkan terus menerus maka akan menghambat potensi yang ada pada diri siswa, dan rendahnya sikap terbuka dalam diri siswa, sikap saling pengertian, saling menghargai dan paling penting saling mengembangkan kualitas hubungan komunikasi siswa kepada orang lain.

Menurut Prayitno \& Amti (dalam Yendi et al., 2013), Bimbingan adalah proses pemberian bantuan yang dilakukan oleh orang yang ahli kepada seseorang atau beberapa orang individu, baik anak-anak, remaja, maupun dewasa agar orang-orang yang dibimbing dapat mengembangkan kemampuan dirinya sendiri dan mandiri, dengan memanfaatkan kekuatan individu dan sarana yang ada dan dapat dikembangkan berdasarkan norma-norma yang berlaku. Selanjutnya Prayitno dan Amti (dalam Yendi et al., 20/3) menyatakan konseling adalah proses pemberian bantuan yang dilakukan melalui wawancara konseling oleh seorang ahli (disebut Konselor) kepada individu yang sedang mengalami suatu masalah (disebut klien) yang bermuara pada teratasinya masalah yang dihadapi klien. 
Sri Mariana', Helmuth Y. Bunu ${ }^{2}$, Nopi Feronika ${ }^{3}$ Jurnal Pandohop

Vol. I, No. I, Tahun 202 I e-ISSN .xxxxxxxxx

Dapat disimpulkan bahwa Bimbingan dan Konseling adalah proses pemberian bantuan yang dilakukan melalui wawancara konseling oleh konselor kepada konseli yang bermuara pada teratasinya masalah yang dihadapi konseli serta dapat memanfaatkan berbagai potensi yang dimiliki dan sarana yang ada sehingga individu atau kelompok itu dapat memahami dirinya sendiri untuk mencapai perkembangan yang optimal, mandiri serta dapat merencanakan masa depan yang lebih baik untuk mencapai kesejahteraan hidup.

Layanan bimbingan kelompok adalah layanan yang memungkinkan sejumlah peserta didik secara bersama-sama memperoleh bahan dari narasumber tertentu (terutama guru pembimbing atau konselor) yang berguna untuk menunjang kehidupan sehari-hari baik individu sebagai pelajar, anggota keluarga, dan masyarakat serta untuk mempertimbangkan dalam pengambilan keputusan. Dengan demikian bimbingan kelompok adalah proses pemberian informasi dan bantuan yang diberikan oleh seorang yang ahli (guru pembimbing) pada sekelompok orang dengan memanfaatkan dinamika kelompok guna mencapai suatu tujuan tertentu, tujuan dalam penelitian ini adalah membentuk konsep diri positif.

Keterbukaan diri adalah proses memberi kesempatan kepada pihak lain untuk mengetahui cara kita berpikir, mengenai perasaan kita tentang sesuatu dan tentang keinginan stimulus yang berasal dari dalam maupun dari luar dirinya. Pengetahuan tentang diri akan meningkatkan komunikasi, dan pada saat yang sama, berkomunikasi dengan orang lain meningkatkan pengetahuan tentang diri kita. Dengan membuka diri, konsep diri menjadi lebih dekat pada kenyataan. Bila konsep diri sesuai dengan pengalaman kita, kita akan lebih terbuka untuk menerima pengalamanpengalaman dan gagasan-gagasan, lebih cenderung menghindari sikap defensif, dan lebih cermat memandang diri kita dan orang lain.

Keterbukaan diri dalam komunikasi adalah kegiatan berbagi informasi tentang suatu pernyataan apa yang disangka, dikira tentang sesuatu (orang, peristiwa) yang tidak didasarkan fakta pembuktian, akan tetapi berdasar pada apa yang dilihatnya seperti benar atau mungkin kepada kawan sebaya secara terbuka dengan mempunyai tujuan dan keinginan yang sama. Dalam brainstorming ini adalah suatu bentuk diskusi dalam rangka menghimpun gagasan, pendapat, informasi, pengetahuan, pengalaman dari semua peserta. Berbeda dengan diskusi dimana gagasan dari seseorang ditanggapi (didukung, dilengkapi, dikurangi, atau tidak disepakati) oleh peserta lain, pada pengguna model brainstorming orang lain tidak untuk ditanggapi.

Dari pengertian di atas, maka dapat ditarik kesimpulan bahwa brainstorming ini menguras habis segala sesuatu yang dipikirkan oleh siswa dalam menanggapi masalah yang dilontarkan guru kepada siswa. Dalam proses ini proses berfikir siswa sangat dituntut untuk mewujudkan potensi kreatifitasnya sehingga siswa dapat terlibat secara aktif dalam pembelajaran.

\section{METODOLOGI}

Penelitian ini berlokasi di MAN Kota Palangka Raya tahun ajaran 2018/2019 yang beralamat di J.Cilik Riwut km.4,5 Palangka Raya. Populasi dalam penelitian ini adalah siswa kelas XI IA 4 MAN Kota Palangka Raya. Pengambilan sampel dengan teknik sampling purposive, penentuan sampel dengan pertimbangan tertentu. Pertimbangan dalam penelitian ini hanya sampel yang ingin diteliti pada siswa yang kurang memiliki keterbukaan diri dalam komunikasi. Kemudian sampel yang telah ditentukan tersebut digabungkan dalam satu kelompok eksperimen. Maka 
sampel yang dilakukan di XI IA 4 MAN Kota Palangkaraya ialah 6 siswa yang memiliki keterbukaan diri rendah. Sehingga didapat sampel dalam penelitian ini berjumlah 6 orang siswa yang terdiri dari 4 orang perempuan dan 2 orang laki-laki.

Penelitian ini merupakan penelitian eksperimen dengan bentuk desain Pre-eksperimental Designs yaitu merupakan penelitian yang mengamati suatu kelompok utama dan melakukan intervensi sepanjang penelitian. Dalam rancangan ini tidak ada kelompok kontrol untuk diperbandingkan dengan kelompok eksperimen (Sugiyono, 2018).

Pelaksanaan penelitian eksperimen ini meliputi tes awal (post test), dan tes akhir (post test) yaitu untuk menguji hasil pelaksanaan Teknik Brainstorming dan kemudian membandingkan hasil dari tes akhir dengan hasil tes awal sebelum penerapan Teknik Brainstorming. Jadi kelompok peneliti gunakan dalam penelitian hanya I kelompok eksperimen.

Teknik Pengumpulan data yang digunakan dalam penelitian ini yaitu: Angket, Observasi dan Dokumentasi. Instrument Penelitian yang digunakan dalam penelitian ini adalah angket meningkatkan keterbukaan diri dalam komunikasi. Angket dalam penelitian ini menggunakan model likert. Model skala likert biasanya terdiri dari 5 jawaban. Teknik analisis data dalam penelitian ini menggunakan statistic non parametris yang digunakan untuk menguji hipotesis kompratif rata-rata dua sampel bila datanya berbentuk interval atau ratio adalah menggunakan t-test.

\section{HASIL DAN PEMBAHASAN}

Tempat dilaksanakannya penelitian adalah di ruang kelas XI IA 4 MAN Kota Palangka Raya. MAN Kota Palangka Raya adalah salah satu sekolah berbasis agama dengan akreditasi A yang terletak di Jl.Cilik Riwut km. 4,5 Palangka Raya. Hasil tahap studi pendahuluan diperoleh data berupa data hasil studi literatur, observasi, dan wawancara. Hasil observasi dan wawancara langsung kepada enam siswa tersebut antaralain: Dari hasil peneliti di MAN Kota Palangkaraya, diketahui ada beberapa siswa yang kurang memiliki sikap kurang terbuka dalam hal berkomunikasi dengan orang lain, seperti I) siswa kurang bersikap berorientasi pada isi. Contohnya siswa yang memilih saat pembagian kelompok karena alasan latar belakang temannya yang berbeda. 2) siswa kurang memiliki sikap mencari informasi dari berbagai sumber. Contohnya saat dapat informasi dari temannya, siswa langsung menerima saja tanpa mencari tau dari yang lain. 3) siswa kurang memiliki sikap mencari pesan tidak sesuai rangkaian kepercayaannya. Contohnya ada siswa saat diskusi/belajar bersama tidak mau terbuka menerima pendapat temannya yang berbeda dengan pendapat dia.

Hal ini sesuai dengan yang dikemukakan oleh Brooks dan Emmert (dalam Rakhmat, 2015), individu dapat dikatakan mampu mengelola emosi dengan baik apabila memenuhi beberapa indikator; (I) menilai pesan secara objektif dengan menggunakan data dan keajekan logika. (2) membedakan dengan mudah, melihat nuansa, dsb. (3) berorientasi pada isi. (4) mencari informasi dari berbagai sumber (5) lebih bersifat profesional dan mengubah kepercayaan. (6) mencari pengertian pesan yang tidak sesuai rangkaian kepercayaannya. Hal ini sesuai dengan data hasil studi literature, observasi wawancara dan bahwa keenam sampel mengalami rendahnya keterbukaan diri dalam komunikasi. Jadi dari hasil studi pendahuluan dengan siswa tersebut mengenai keterbukaan diri dalam komunikasi menunjukkan bahwa perlu adanya pemberian bimbingan kelompok dengan teknik brainstorming kepada siswa. Hal ini dikarenakan penguasaan siswa dalam meningkatkan keterbukaan 
Sri Mariana', Helmuth Y. Bunu ${ }^{2}$, Nopi Feronika ${ }^{3}$ Jurnal Pandohop

Vol. I, No. I, Tahun 202I e-ISSN .xxxxxxxxx

diri dalam komunikasi masih rendah. Berikut adalah hasil analisis data presentase dari keenam sampel:

Tabel I. Analisis Data Persentase Nilai Pre-Test

\begin{tabular}{|c|c|c|c|c|}
\hline \multirow{2}{*}{ No } & \multirow{2}{*}{$\begin{array}{l}\text { Kode } \\
\text { Siswa }\end{array}$} & \multicolumn{3}{|c|}{ Pre Test } \\
\cline { 3 - 5 } & & Jumlah & Presentase & Kategori \\
\hline I & M.H.A & 66 & $55 \%$ & Sedang \\
\hline 2 & N.A & 62 & $52 \%$ & Sedang \\
\hline 3 & R.S.A & 60 & $50 \%$ & Rendah \\
\hline 4 & R & 55 & $46 \%$ & Rendah \\
\hline 5 & T.R & $6 I$ & $51 \%$ & Rendah \\
\hline 6 & F.S & 58 & $48 \%$ & Rendah \\
\hline \multicolumn{2}{|c}{ Rata-Rata } & $\mathbf{6 0 , 3 3 3 3}$ & $\mathbf{5 0 \%}$ & Rendah \\
\hline
\end{tabular}

Tabel II. Analisis Data Presentase Nilai Post-test setelah diberikan Bimbingan Kelompok dengan Teknik

Brainstorming

\begin{tabular}{|c|c|c|c|c|}
\hline \multirow{2}{*}{ No } & Kode & \multicolumn{3}{|c|}{ Post Test } \\
\cline { 3 - 5 } & Siswa & Jumlah & Presentase & Kategori \\
\hline I & M.H.A & 89 & $74 \%$ & Tinggi \\
\hline 2 & N.A & 84 & $70 \%$ & Tinggi \\
\hline 3 & R.S.A & 82 & $68 \%$ & Tinggi \\
\hline 4 & R & 78 & $65 \%$ & Sedang \\
\hline 5 & T.R & 75 & $63 \%$ & Sedang \\
\hline 6 & F.S & 85 & $71 \%$ & Sedang \\
\hline \multicolumn{6}{|l}{ Rata-Rata } & $\mathbf{8 2 , 1 6 6 7}$ & $\mathbf{6 9 \%}$ & Tinggi \\
\hline
\end{tabular}

Tabel III. Analisis Data Sebelum (Pre-test) dan Sesudah (Post-test) diberikan Bimbingan Kelompok dengan Teknik Brainstorming.

\begin{tabular}{|c|c|c|c|c|c|c|}
\hline \multirow[b]{2}{*}{$\begin{array}{l}\mathrm{N} \\
\mathrm{O}\end{array}$} & \multirow[b]{2}{*}{$\begin{array}{l}\text { Kode } \\
\text { Siswa }\end{array}$} & \multicolumn{2}{|c|}{ Pre test } & \multicolumn{2}{|c|}{ Post Test } & \multirow{2}{*}{$\begin{array}{c}\% \\
\text { Skor } \\
\text { Peni } \\
\text { ngka } \\
\tan \end{array}$} \\
\hline & & $\begin{array}{c}\% \\
\text { Skor }\end{array}$ & Kriteria & $\begin{array}{c}\% \\
\text { Skor }\end{array}$ & Kriteria & \\
\hline 1 & M.H.A & $55 \%$ & Sedang & $74 \%$ & Tinggi & $19 \%$ \\
\hline 2 & N.A & $52 \%$ & Sedang & $70 \%$ & Tinggi & $18 \%$ \\
\hline 3 & R.S.A & $50 \%$ & Rendah & $68 \%$ & Tinggi & $18 \%$ \\
\hline 4 & $\mathrm{R}$ & $46 \%$ & Rendah & $65 \%$ & Sedang & $19 \%$ \\
\hline 5 & T.R & $51 \%$ & Rendah & $63 \%$ & Sedang & $12 \%$ \\
\hline 6 & F.S & $48 \%$ & Rendah & $71 \%$ & Sedang & $23 \%$ \\
\hline \multicolumn{2}{|c|}{ Rata-Rata } & $50 \%$ & $\begin{array}{c}\text { Renda } \\
h\end{array}$ & $\begin{array}{l}\text { Ren } \\
\text { dah }\end{array}$ & $69 \%$ & $\begin{array}{l}\text { Tin } \\
18 \%\end{array}$ \\
\hline
\end{tabular}

Selain itu analisis data yang digunakan untuk mengetahui apakah keterbukaan diri dalam komunikasi benar-benar bisa ditingkatkan melalui bimbingan kelompok teknik brainstorming yaitu dengan menggunakan teknik analisis uji $\mathrm{T}$ dua sampel berpasangan. Berdasarkan analisis data diperoleh $\mathrm{t}$ hitung yaitu $(-12,548)$ sedangkan untuk nilai t tabel dalam penelitian ini yaitu $(-2,015)$.

Dari tabel III Analisis Data Sebelum (Pretest) dan Sesudah (Posttest) diberikan Bimbingan Kelompok dengan Teknik Brainstorming dapat dilihat persentase rata-rata tingkat keterbukaan diri dalam komunikasi sebesar $69 \%$ meningkat dari sebelumnya pada saat pre test sebesar 50\%. Jumlah tersebut mengalami persentase peningkatan rata-rata sebesar 18\%. Tentunya hal ini menunjukkan bahwa keterbukaan diri dalam komunikasi pada siswa dapat ditingkatkan melalui bimbingan kelompok teknik Brainstorming. Berdasarkan analisis data diperoleh $t$ hitung yaitu $(-12,548)$ sedangkan untuk nilai t tabel dalam penelitian ini yaitu $(-2,0 / 5)$. Hal ini menunjukkan bahwa $t_{\text {hitung }}(-12,548)<t_{\text {tabel }}(-2,015)$ maka $H_{0}$ ditolak dan $H_{a}$ diterima. Ini berarti penerapan bimbingan kelompok teknik Brainstorming dapat membantu siswa kelas XI IA 4 MAN Kota Palangka Raya dalam meningkatkan keterbukaan diri dalam komunikasi.

Gambar I. Pelaksanaan Bimbingan Kelompok

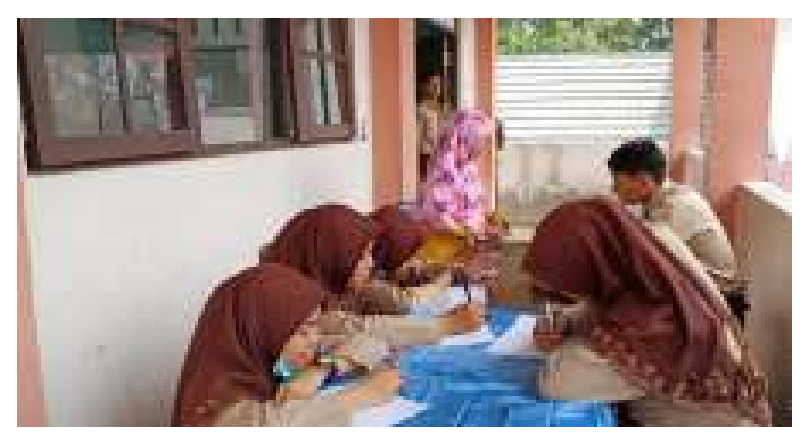

\section{KESIMPULAN}

Berdasarkan hasil angket pretest dan posttes mengenai keterbukaan diri dalam komunikasi dengan menggunakan bimbingan kelompok teknik 
brainstorming mengunkanan analisis statistic uji $\mathrm{t}$ dua sampel berpasangan diperoleh hasil $t_{\text {hitung }}(-12,548)$ sedangkan $t_{\text {tabel }}(-2,015)$ dimana hal ini menunjukkan bahwa $t_{\text {hitung }}(-12,548)<t_{\text {tabel }}(-2,015)$ maka $H_{0}$ ditolak. Ini berarti menunjukkan ada perbedaan ratarata nilai pretest dan postest setelah diberikan bimbingan kelompok dengan teknik Brainstorming. Dari hasil tersebut peneliti menyimpulan bahwa bimbingan kelompok dengan teknik Brainstorming efektif untuk meningkatkan keterbukaan diri dalam komunikasi siswa kelas XI IA 4 MAN Kota Palangka Raya.

Saran bagi Sekolah yaitu bimbingan kelompok teknik brainstorming dapat dijadikan sebagai salah satu strategi alternatif dalam meningkatkan keterbukaan diri dalam komunikasi. Sedangkan bagi guru BK Teknik brainstorming dalam menjadi alternatif mampu meningkatkan keterbukaan diri siswa dalam komunikasi. Untuk Siswa diharapkan dapat meningkatkan keterbukaan dirinya sehingga dapat mengembangkan potensi dirinya secara optimal.

\section{REFERENSI}

Ashfahani, S. (2019). Implementasi Keterbukaan dan Dukungan dalam Komunikasi Antarpribadi (Studi Komunikasi Pimpinan dan Karyawan di Sekolah Tinggi Ilmu Kesehatan Indonesia Maju). Jurnal IImiah Komunikasi (JIKOM) STIKOM IMA, II(0I), I87-I 95.

Rakhmat, J. (20I5). Psikologi komunikasi.

Sugiyono. (2018). Metode Penelitian

Kuantitatif,Kualitatif dan R\&D. In ke-26.

Suriana, A., \& Dewi, D. S. E. (2013). Penelitian Tentang Self Disclosure Pasien ODHA RSUD Banyumas. Psycho Idea, II(I).

Yendi, F. M., Ardi, Z., \& Ifdil, I. (20/3). Pelayanan Konseling untuk Remaja Putri Usia Pernikahan. Jurnal Konseling Dan Pendidikan, I(2), I09-II4. 